\title{
ITF

\section{Exercises to improve the head position in tennis strokes}

\author{
Manuel Fernández López
}

ABSTRACT

Tennis is an opposition sport in which we hit the ball with the racket whilst in movement, attempting to place it as far away from our opponent as possible but within the court. It is also a high-speed interception sport, and the speed increases with the level of the players. This article presents different specific on-court exercises to help players to improve their capacity to adapt to changing tennis dynamics.
Key words: vision, balance, fixing, impact.

Received: 10 May 2020

Accepted: 29 July 2020

Corresponding author;

Manuel Fernández López,

Spain. Email:

tennisplus.manu@gmail.com

\section{INTRODUCTION}

A review of scientific studies on this subject leads us to conclude that it is probable that the most skilled and successful players, and almost certainly professional players, try to anticipate the zone where they think the ball will bounce, i.e. they try to anticipate the flight of the ball, so as to be in a better position to hit it. This can also help players to anticipate the variations the ball may undergo during the bounce (Lafont, 2008).

As a player starts fixing your eyes and your head ("gaze"), they start searching for motor solutions to several challenges at the same time, one is stability at impact, and another is maintaining high concentration at the time of impact (including a just before and after), so as not to lose concentration on other aspects such as the target or the position of the opponent. This loss of concentration can be related to the anxiety or stress generated by the importance of a point (subjective to the player) (Luis del Campo, Reina, Sabido, \& Moreno, 2015).

The work of the coach with regard to these questions consists of practical interventions to help the player manage the game dynamics. In short, two kinds of work are suggested: dynamic stability at impact and concentration at impact.

\section{WORKING ON STABILITY AT IMPACT}

The more power a player intends to hit the ball to the other side of the net with, the greater the stability should be; therefore, the further away a player is from their PHV and their highest level of play, the greater the amount of training on stability and head-eye fixations players should undertake.
Hitting exercises with rubber bands, throwing with the medicine ball, and with free weight exercises (e.g. dumbbells, etc.) which are used to train strength, can be used to train stability. Any hitting exercise, with or without a ball, including strength exercises above, on unstable surfaces (e.g. a bosu balance trainer, kneeling on a "fitball" and hitting on a balance disk) will be appropriate for attaining this goal.

Exercises that simulate the real game will help obtain the most appropriate conditions to observe, evaluate, and train hitting stability at impact. This is due to the fact that since each decision on how much power to hit the ball and body position will be unique and differ from shot to shot. (Shafizadeh, Bonner, Fraser \& Barnes, 2019).

This variability in the game makes it necessary to consider the following shot, not as something to practice separately, but to integrate into the aforementioned exercises; still, some isolated strength training routines may be useful in reducing or eliminating uncertainty.

\section{WORKING ON CONCENTRATION AT IMPACT}

Concentration is key in tennis, and during the different phases of the stroke, players must focus attention on: the right direction (as previously discussed); the moment of impact (and even before the ball arrives); and, focusing on the area where the ball is expected to bounce or on the impact zone. All this helps to manage pressure, anxiety or stress, and at the same time, to be more accurate when trying to hit the target or aiming for a certain direction. 
Quiet Eye (QE) helps to gather information on the bounce of the ball, subconsciously taking place as a high speed reaction and also relying on the information gathered on the position of the opponent and/or the movements detected, and this will help to anticipate the tactics that should be used.

We must bear in mind that training strokes with a target or tactic in mind must be done as soon as possible given that technique without a target makes no sense, and when the player gets used to having a target, accuracy, direction and attention come into play. In order to more-than-adequately attend to the impact zone, it is necessary to have a good orientation of the player's situation on court since this will affect the different characteristics such as height, spin or speed (Keller \& Ripoll, 2006).

The attention on the target or on the opponent means that there will be reduced attention on the impact zone, and therefore that stroke will not be that accurate. This will not be a case of a high or low percentage, it will be on an internal scale that the player must learn to detect, evaluate and balance. Whilst QE helps to gather important information about learning, keeping it focused on the impact zone can build a continuous learning relationship in each stroke, allowing for consideration of the many factors that the body unconsciously perceives for its own benefit, learning from the experiences lived, and using them for future situations (Giblin, Whiteside \& Reid, 2017).

\section{EXERCISES} differences in different stages, also providing a progression for players.

It must be kept in mind that the evolution presented could be a strategy in itself, appropriate for some types of players, but not all, since individualisation and adaptation of training to the player characteristics is key (gender differences are not considered as we posit that speed and accuracy depend on the same factors for all, regardless of the tactics used in the game) (Elliott, Reid \& Crespo, 2009).

Images are attached to some of the exercises (image number in brackets)
Table 1 shows some proposed exercises. It discusses the training

\begin{tabular}{|c|c|c|}
\hline Stage & Exercise & Observations \\
\hline \multirow{4}{*}{$\begin{array}{l}\text { General } \\
\text { (in all) }\end{array}$} & $\begin{array}{c}\text { Throwing the medicine ball or other lighter } \\
\text { or heavier objects (image 1). }\end{array}$ & \multirow{4}{*}{$\begin{array}{c}\text { These exercises can } \\
\text { be used at any stage, } \\
\text { and the equipment } \\
\text { and/or weight is } \\
\text { adapted to the } \\
\text { characteristics, level } \\
\text { and biologic age of } \\
\text { the players. }\end{array}$} \\
\hline & $\begin{array}{l}\text { Hitting with dumbbells, rubber bands or } \\
\text { toning bands with different weights (image } \\
\text { 2). }\end{array}$ & \\
\hline & $\begin{array}{l}\text { Hitting with targets, real game like situations } \\
\text { and real matches (image 3). }\end{array}$ & \\
\hline & $\begin{array}{l}\text { Hitting with or without a ball, or weight } \\
\text { /(dumbbells, rubber bands or tonings) on } \\
\text { unstable surfaces or objects (bosu balance } \\
\text { trainer, fitball and balance disk (image } 2 \& \\
\text { 3)). }\end{array}$ & \\
\hline \multirow[b]{2}{*}{$\begin{array}{l}\text { Beginner and } \\
\text { intermediate } \\
\text { (competition } \\
\text { prior to } \\
\text { juniors). }\end{array}$} & $\begin{array}{l}\text { On court orientation - hitting and throwing } \\
\text { from different points and playing games } \\
\text { using zones (back, middle (image 4) and net), } \\
\text { etc. }\end{array}$ & \multirow{2}{*}{$\begin{array}{l}\text { When doing the } \\
\text { exercises, it is } \\
\text { necessary to provide } \\
\text { the instruction to } \\
\text { maintain head } \\
\text { position, and to } \\
\text { avoid looking at the } \\
\text { target or the target } \\
\text { zone (this must be } \\
\text { explained, for it is } \\
\text { natural to hit looking } \\
\text { at the targets). }\end{array}$} \\
\hline & $\begin{array}{l}\text { Hitting and throwing with big targets (cones } \\
\text { (image 5), goal targets, air rings (hula hoops), } \\
\text { rope over the net height, etc.). }\end{array}$ & \\
\hline \multirow{2}{*}{$\begin{array}{c}\text { Junior } \\
\text { competition }\end{array}$} & $\begin{array}{l}\text { Concentration during the stroke under } \\
\text { pressure (with distracting noises, decisive } \\
\text { points with penalties, etc.) }\end{array}$ & \multirow{2}{*}{$\begin{array}{l}\text { Match and training } \\
\text { video recordings for } \\
\text { analytical use later } \\
\text { on can help evaluate } \\
\text { levels of } \\
\text { concentration at } \\
\text { impact. }\end{array}$} \\
\hline & $\begin{array}{l}\text { Hitting and rallying whilst aiming at small } \\
\text { targets (cones, lines and balls) (image } 6 \text { ). }\end{array}$ & \\
\hline \multirow{4}{*}{$\begin{array}{l}\text { Professional } \\
\quad \text { (top } \\
\text { performance) }\end{array}$} & $\begin{array}{l}\text { Strength training at high speeds looking to } \\
\text { push the limit of the movement whilst } \\
\text { maintaining balance and optimum } \\
\text { movement of the joints (image 1). }\end{array}$ & \multirow{4}{*}{$\begin{array}{l}\text { Video recordings } \\
\text { may be very useful } \\
\text { for later } \\
\text { observation. } \\
\text { At this stage, it is } \\
\text { important to place } \\
\text { emphasis on } \\
\text { adequate nutrient } \\
\text { replenishment of the } \\
\text { muscles and a good } \\
\text { work-rest balance } \\
\text { (and also to have } \\
\text { appropriate } \\
\text { routines), due to } \\
\text { high workloads, both } \\
\text { in volume and in } \\
\text { intensity. }\end{array}$} \\
\hline & $\begin{array}{l}\text { Repeated strokes for transference of } \\
\text { strength to the court, and accuracy in } \\
\text { relation to the movements (image 7). }\end{array}$ & \\
\hline & $\begin{array}{l}\text { Situations of maximum pressure and stress, } \\
\text { as close to competition as possible, or in } \\
\text { competition, aiming for maximum } \\
\text { concentration at impact, and maintaining the } \\
\text { eyes-head position timed correctly in order } \\
\text { to see the next impact and maintain the rally } \\
\text { (image } 8 \text { ). }\end{array}$ & \\
\hline & $\begin{array}{l}\text { Hitting or rallying with less or more time to } \\
\text { prepare (image 9). }\end{array}$ & \\
\hline
\end{tabular}

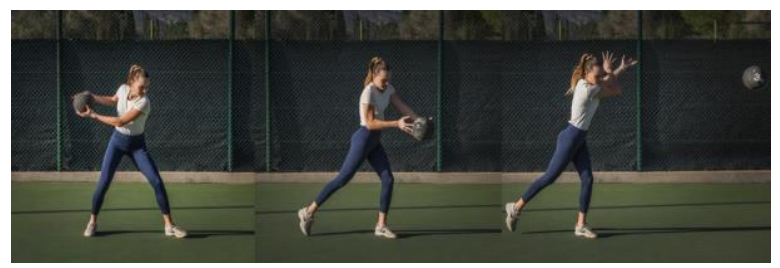

Image 1. Medicine ball throw.

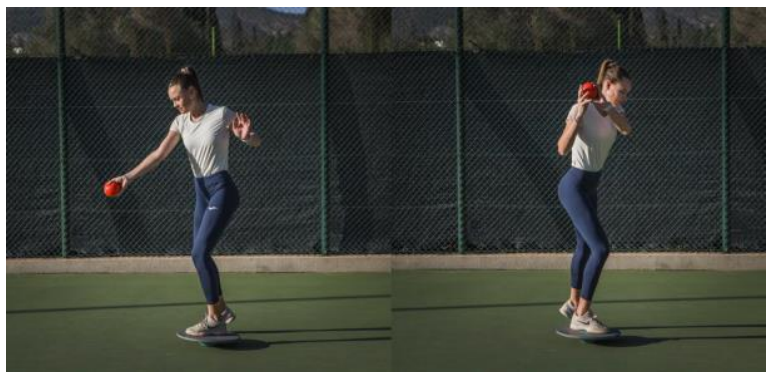

Image 2. Hitting with toning ball on a balance disk (right and left) 


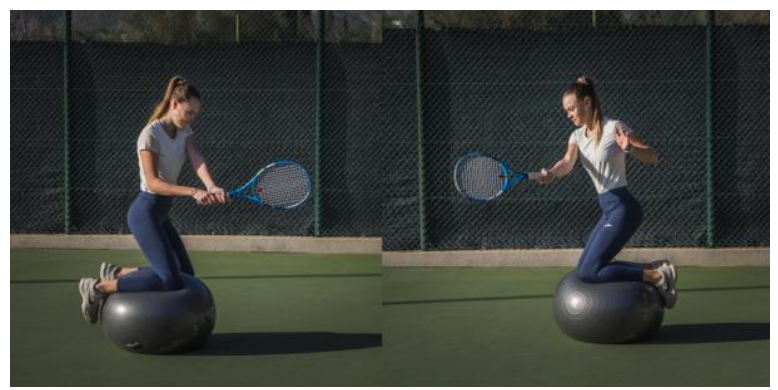

Image 3. Forehand and backhand on unstable surface (fitball).

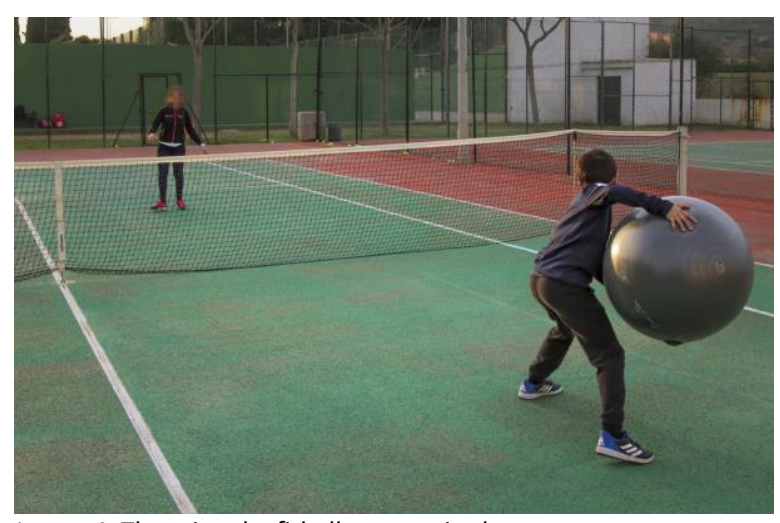

Image 4. Throwing the fitball to a service box.
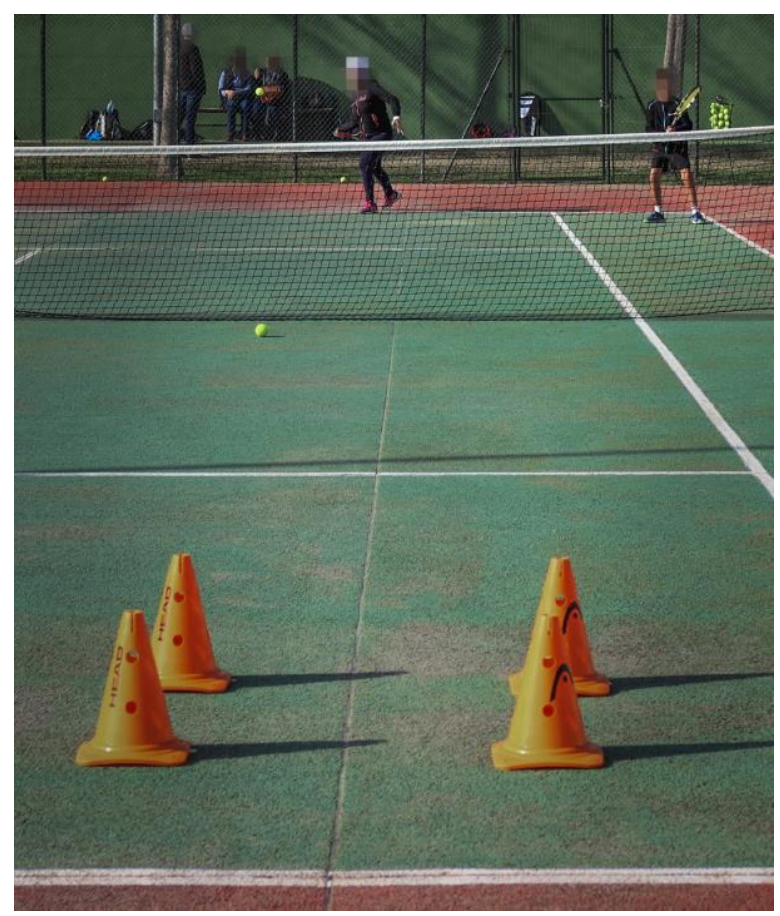

Image 5. Hitting from different court zones towards a big target.

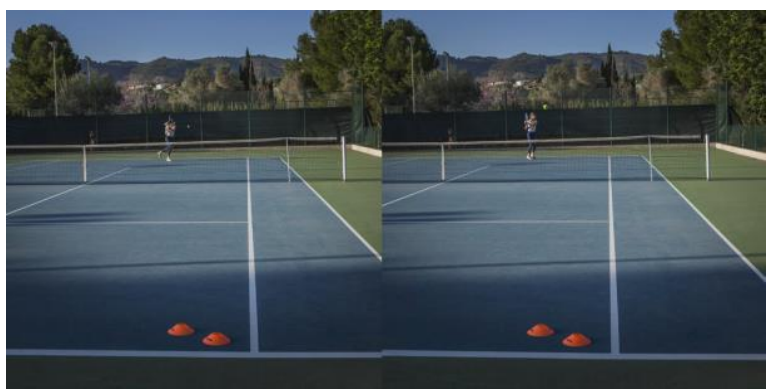

Image 6. Backhand towards a small target.

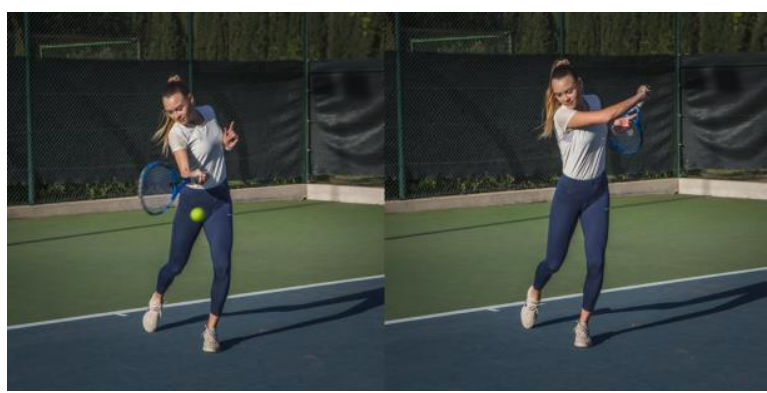

Image 7. Hitting after launching the medicine ball, (see image 1), looking for transference.

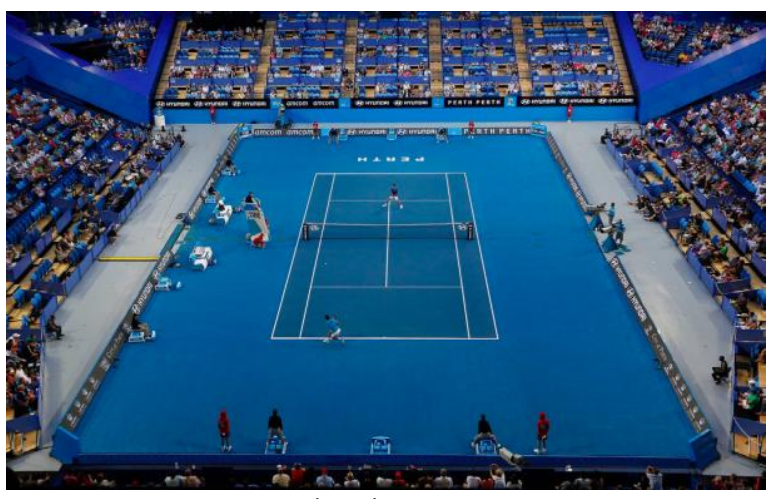

Image 8. Competition match under pressure.

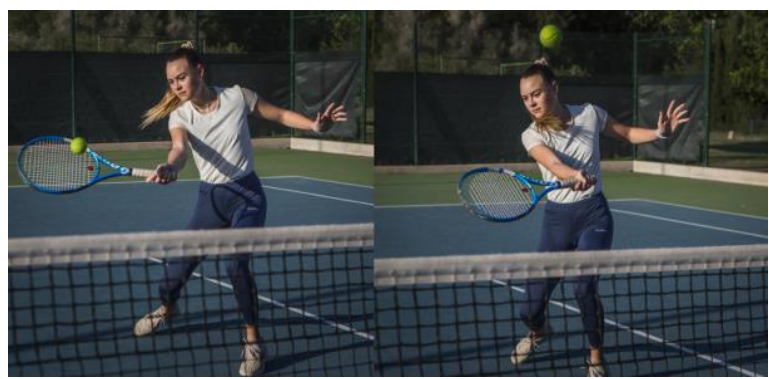

Image 9. Rallying volleys with little time to keep the eye-headcontact connection.

Photographer: Laida Jauregui Salvia (Except image 8).

\section{CONCLUSIONS}

The outcome of the research shows a direct relationship between the stability and maintenance of position of the head with the 
experience and level of the players. Furthermore, fixing the "gaze" on the impact zone, helps to increase attention and improve accuracy when hitting towards a target and under pressure.

It is therefore key to bear in mind that the vision of the ball plays a fundamental role in stroke production, that is why it is key to train this from an early age.

\section{REFERENCES}

Elliott, B., Reid, M. \& Crespo, M. (2009). El desarrollo de la técnica en la producción de los golpes de tenis. ITF The international tennis federation, Ed. Primera.

Giblin, G., Whiteside, D. \& Reid, M. (2017). Now you see, now you don't ... the influence of visual occlusion on racket and ball kinematics in the tennis serve. Sports Biomechanics, 16(1), 23-33, https://doi.org/10.1080/14763141.2016.1179337

Keller, J. \& Ripoll, H. (2006). Cognition and the emergence of coordination in performing hitting a tennis ball in nine-year-old children. Trends in learning research, chapter 7, pp. 139-170.

Lafont, D. (2008). Gaze control during the hitting phase in tennis: a preliminary study. International Journal of Performance Analysis in Sport, 8(1), 85-100, https://doi.org/10.1080/24748668.2008.11868425

Luis del Campo, V., Reina, R., Sabido, R., \& Moreno, F. J. (2015). Diferencias en el comportamiento visual y motor de tenistas en laboratorio y en pista de tenis. Revista Latinoamericana de Psicología, 47(2), 136-145, https://doi.org/10.1016/j.rlp.2015.05.003

Shafizadeh, M., Bonner, S., Fraser, J., \& Barnes, A. (2019). Effect of environmental constraints on multi-segment coordination patterns during the tennis service in expert performers. Journal of sports sciences, 37(9), 1011-1020, https://doi.org/10.1080/02640414.2018.1538691

RECOMMENDED ITF TENNIS ACADEMY CONTENT (CLICK BELOW)

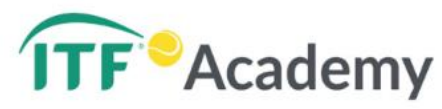

Copyright (c) 2020 Manuel Fernández López

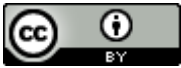

This text is under a Creative Commons BY 4.0 license

You are free to Share - copy and redistribute the material in any medium or format - and Adapt the content - remix, transform, and build upon the material for any purpose, even commercially under the following terms:

Attribution: You must give appropriate credit, provide a link to the license, and indicate if changes were made. You may do so in

any reasonable manner, but not in any way that suggests the licensor endorses you or your use.

CCBY4.0license terms summary CCBY4.0license terms 